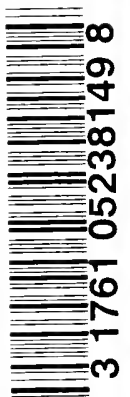

i.

as

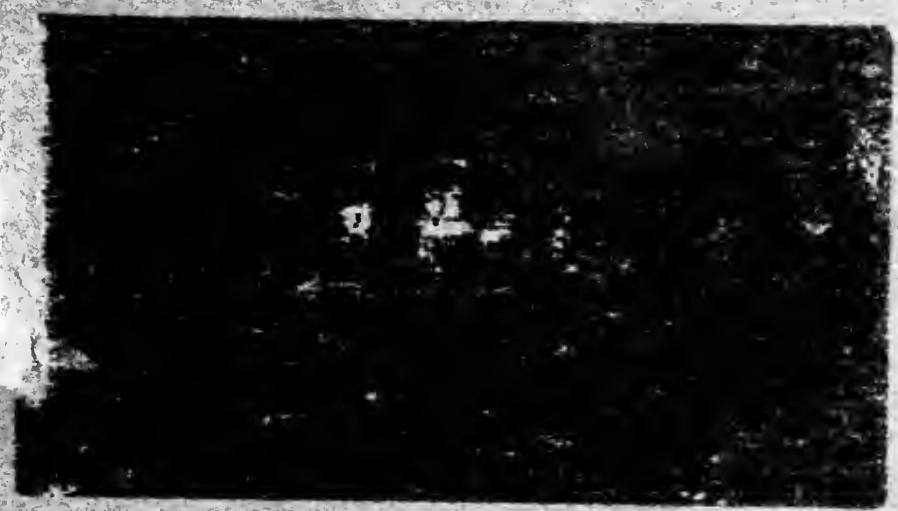


Digitized by the Internet Archive in 2008 with funding from Microsoft Corporation 



\title{
Alniversity of Coronto.
}

\author{
PAPERS
}

FROM THE

\section{CHEM ICAL LABORATORY.}

irn. 5. The Chemical Industries of Canada.

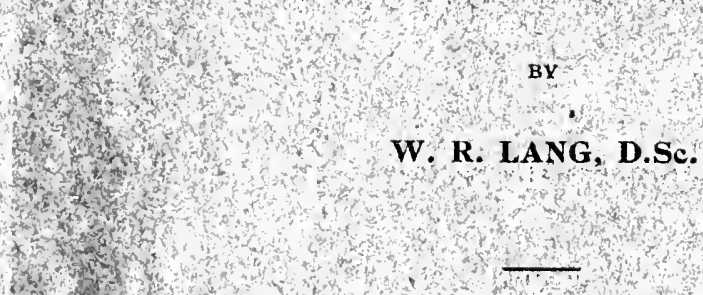

Reprinted from the Journal of the socicty of Chemical Industry, May 15,1903 .

\section{TORONTO, 1903.}





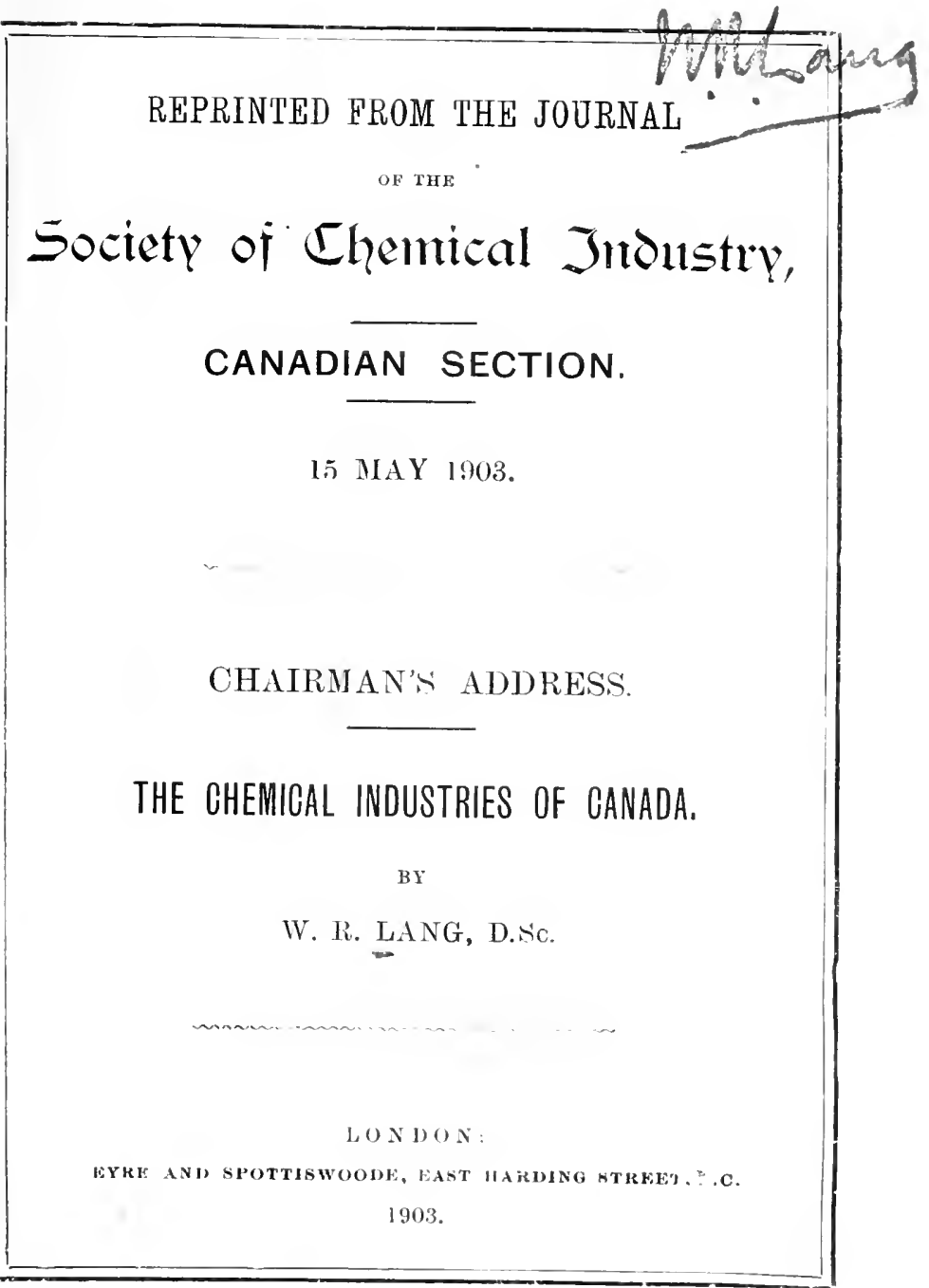




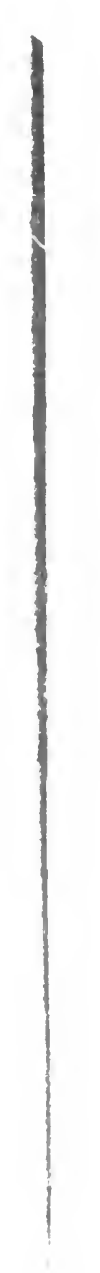




\section{REPRINTED FROM THE JOURNAL}

OF THE

\section{Society of Chemical Jnoustry,}

\section{CANADIAN SECTION.}

\section{MAY 1903.}

\section{CHAIRMAN'S ADDRESS.}

THE CHEMICAL INDUSTRIES OF GANADA.

$$
\begin{gathered}
\text { BY } \\
\text { W. R. LANG, D.Sc. }
\end{gathered}
$$

\section{ONDON :}

EYRE AND SPOTTISWOODE, EAST HATDING STRFET, E.C. 1903. 

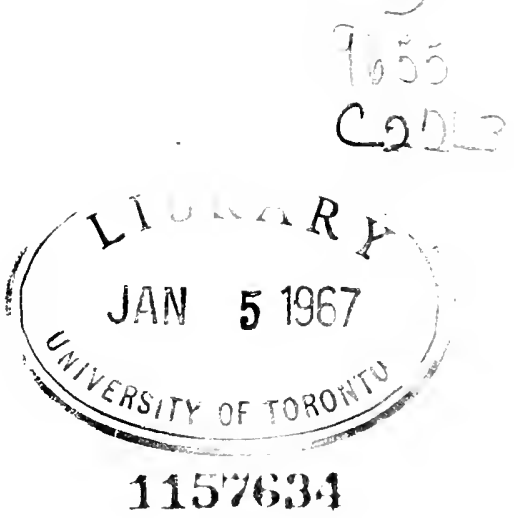
[Reprinted from the Journal of the Society of Chemical

Industry, 15 LFay 1903. No. 9, Vol. XXII.]

\title{
Camadian Errtion.
}

\author{
Meeting held at Toronto, on Wednesday,
}

Mayj 6th, 1903.

DR. IIAROLD VAN DER LINDE (VICE-CHAIRMAN) IN THE CHAIR.

\section{CHAIRMAN'S ADDRESS.}

\section{THE CHEMICAL INDUSTRIES OF CANADA.}

\author{
BY W. R. LANG, D.sc.
}

In selecting a subject for an address as the first Chairman of the Canadian Section of this Society, two main considerations have been kept in mind; firstly, that the development of the industrial resources of the Dominion during the past decade has been phenomenal, and, secondly, that the extent of these developments is only fully understood by a few, while it is almost unknown to our fellow members in Britain. While it is impossible to discuss all the industries in which chemical operations and reactions are made use of, an attempt has been made to select processes in some cases peculiar to the country, but notably the industries which owe their development to the natural, mineral, and vegetable resources, and to the widely scattered water power obtainable in the Dominion.

The subjects taken up may be classified as follows:-

I.-Common Salt, Alkali, and Chlorine Compounds.

II.--The Extraction and Refining of Metals.

III.-The Leather and Tanning Industries.

IV.-Sulphuric Acid, Acetic Acid, Wood Alcohol, Charcoal, and Ammonia.

V.-Soap and Glycerin.

VI.-Refined Chemicals and Drugs.

VII-Fertilisers.

P 7298. -5 . 
VIII.-Coal-Tar and Asphalt.

IX.-Calcium Carbide, Carborundum, and Graphite.

X.-.-The Cement and Plaster Industry.

XI.-Carbohydrates: Divided into-

(a) The Refining of Sugar.

(b) The Beet-Sugar Industry.

X1I.-Natural Gas and Petroleum.

XIII.-Pulp and Paper.

XIV.-Asbestos.

\section{I.-Common Salt, Alkali, and Chlorine Compounds.}

Sodinm chloride is found in the Upper Silurian beds in Ontario and in the Devonian in Manitoba and Athabasca; salt springs also occur in Cape Bretoll and in New Brunswick, but these are comparatively unimportant sources of supply. In Ontario the salt area stretches through the counties of Middlesex, Huron, Bruce, and Lambton, large deposits being found along the shore of Lake Huron from Kincardine to IVindsor. At Coderich there is a deposit $126 \mathrm{ft}$. thick, and at Windsor a well extending to a depth of 1,672 feet passes through four beds of rock salt of an aggregate thickness of $392 \mathrm{ft}^{1}$ The salt is obtained by evaporation, and is of an exceilent quality. The following comparison serves to illustrate the purity of the natural product. $^{2}$

\begin{tabular}{|c|c|c|}
\hline & $\begin{array}{l}\text { Natural Salt } \\
\text { of Coderich, } \\
\text { Ontario. }\end{array}$ & $\begin{array}{l}\text { Natural Salt } \\
\text { of Cheshire } \\
\text { (England). }\end{array}$ \\
\hline \multirow[t]{3}{*}{ 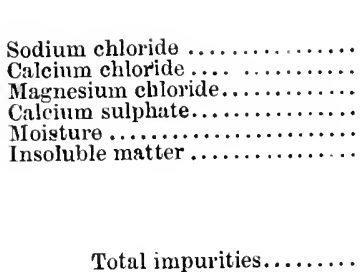 } & $\begin{array}{c}\text { Per Cent. } \\
99 \cdot 687 \\
0.032 \\
0.095 \\
0.090 \\
0.079 \\
0.017\end{array}$ & $\begin{array}{c}\text { Per Cent. } \\
96 \cdot 70 \\
0 \cdot 68 \\
0 \cdot 00 \\
0 \cdot 25 \\
0 \cdot 63 \\
1 \cdot 74\end{array}$ \\
\hline & $100 \cdot 000$ & 100.000 \\
\hline & 0.234 & $2 \cdot 67$ \\
\hline
\end{tabular}

1 W. Hodgson Ellis, M.B., in “A Handbook of Canida," 1897.

3 Wilmott, A. B., "Some Minor Minerals of Canada," 1897. 
The total production of salt in Canada was valued in 1892 at 162,000 dols., and in 1901 at 262,328 dols.

Apart from its uses as a seasoning and as a preservative, common salt is employed in the electrolytic preparation of caustic soda and bleaching compounds. (A full description of this industry was given in a paper read before the Society in Toronto by MIr. B. E. F. Rhodin in 1902. See this Journal, 1902, 449 ).

The alkali and bleaching powder industries througbout the world are at the present time in an unsettled condition, mainly owing to the adrent of electrolytic methods. ${ }^{3}$ Wherever cheap water power is available, however, electrolytic processes will be rapidly developed.

\section{1.-The Extraction and Refining of Metals.}

Almost every province in the Dominion possesses valuable mineral resources; these are rapidly being exploited, and among the metals produced in quantity may be mentioned iron, copper, lead and silver, nickel, arsenic, antimony, and, lastly, aluminium. These metals are found in the form of native iron, magnetic iron ore, iron pyrites, hæmatite, native copper, chalcopyrite, galena, native silver, and ores of silver, nickeliferons pyrrhotite, gold, sulphide of antimony, and arsenical pyrites.

Iron.-The iron ores of the Dominion occur at varicd intervals, from Vancouver Island, on the rest, to Cape Breton Island and Newfoundland on the east. In Nova Scotia there are particularly rich deposits, and in close contiguity to them are fonnd the necessary materials for smelting. Hæmatites, too, are found in all parts of Canada. One of the most ralnable deposits of specular iron is at Hull, near Ottawa, which assays from 64 to 68 per cent. of metallic iron. In the Appendix (Appendix I.) will be found more particulars regarding the iron ores of the Dominion.

The Canadian iron industry dates back to the establishment of the St. Maurice forges by the French Government in 1737. Many other minor plants were subsequently built, as at Batiscan, Hull, and Bois St. Panl, all in Quebec ; at Furnace Falls, Mormondale, Marmora, \&c., in Ontario; at Woodstock, in New Brunswick; and at Moose River, Nictaux, and Bloomfield, in Nova Scotia. They all

s Chem. Tr. J., 23. $.02,6.9 . n 2$, and 24.1.03. 
subsequently failed, however, in consequence of the competition of Great Britain and the United States. This early failure was due as inuch as anything else to lack of enterprise, capital, and proper shipping facilities. The modern development of the industry may be said to date from the iutroduction of a protective duty on iron in 1887. The granting of bounties by the Dominion and Ontario Governments bas also assisted largely in bringing about the present condition of the iron and steel industries.4 The annual aggregate capacity of the completed and unfinished furnaces in the Dominion in 1901 was close on $1,000,000$ gross tons. ${ }^{5}$ Much of the iron prorluced is now being made iuto steel ${ }^{6}$ by the Bessemer process. At Sault Ste. Marie an exteusive plant has recently been completed, with a capacity of 200,000 tons of ingots and 180,000 tons of finished products. There, steel rails are being made for the first time on Canadian soil. At Collingwood, Ontario, the Cramp Steel Co. expect to have an ontput from their new works of from 100 to 120 tons per day, finished into small-size material suitable for blacksmith's and machinist's use. The works of this Company, which are not yet completed, consist of a 250 -ton blastfurnace-to be finished this season-and two 20-ton open-hearth steel-furnaces, beside rolling mills. In these furnaces will be utilised equal amounts of pig and scrap iron; the furnaces are lined with magnesite, and the Gilchrist-Thomas basic process will be employed. 'The machinery for the plant is actuated by electric and hydraulic power, while the cranes are hydraulic entirely. It is claimed that the rclling mills will be the finest in the country. ${ }^{\overline{7}}$ On the eastern seaboard of the Dominion are situated the works of the Dominion Iron and Steel Co., begun in 1899. This company has a capital of $20,000,000$ dols. common stock, besides $5,000,000$ dols. 7 per cent. preferred 'stock and $8,000,600$ dols, in 5 per cent. bouds. An arrangement has also been entered into with the

4 Dominion bounty on pig iron, 3 dols. per ton produced. Ontario bounty, 1 dol. per ton on phe produced from Ontario ores, and 50 cents on ores not obtained in the provinee; the rate of $I$ dol. to be only paid up to 25,000 tons. Bounty is at present largely rednced, owing to increased production.

5 Statistical Year Book of Canarla, 1901, p. 160.

${ }^{6}$ Dominion bounty on steel, 3 do's. per ton; a dols. per ton on steel from foreign ores.

7 Letter from Mr. J. A. Curric. 
Dominion Coal Co. for a 99 years' lease, paying for the privilege 6 per cent. on $20,000,00$ ? dols. common stock of the latter company. Coal and limestone are found comparatively near at hand, the farthest afield mine from which the coal supply is drawn being 25 miles distant, while the nearest one is 6 miles. There is no lack of this mineral, the output being now from 3 to $3 \frac{1}{2}$ million tons per anuum, as compared with 800,000 tons in 1898. Nearly all the iron ore at present used is brought from mines owned by company on Great Belle Island, in Conception Bay, Newfoundland, some 400 miles from syduey. This mine is estimated to contain 28 million tons of arailable ore, besides areas under the sea, which are believed to be very exteusive. Analyses of the ore show it to contain 50 per cent. of iron, little sulphur, but rather too much silica, aluminium, and phosphorus. The result is a pig iron too high in phosphorus, but during the subsequent conversion of the pig into steel in open-hearth furnaces, this impurity is eliminated, and a fine quality of steel produced. For the best kind of pig iron, it is necessary to mix other ores with it, and for this purpose Cuban, Spanish, and Swedish ores are used, the result being a low phosphorus pig. Indications of large deposits of high-grade ores have been found both in Nova Scotia and Cape Breton, which, when fully developed, will in a great measure replace the foreign ores.

Limestone is obtained from the company's quarries at the Bras d'Or Lakes, about 85 miles, by water, from the works. It is a stone of good quality, and is found in large deposits; it acts well with the Newfoundland ore and the Cape Breton coke. ${ }^{8}$ The works contain four blastfurnaces capable of yielding 1,000 tons of pig iron per day; the furnace gases are utilised also to the ntmost, being used to beat the blast and also to raise steam. The iron produced is partly cast into pigs and in part couvesed in a molten condition direct to the open-hearth furnaces, where it is converterl into steel. Of these there are 10 in number, of the H. H. Campbell type of tilting basic openhearth furnaces, having a capacity of 50 tons each. A very complete arrangement of testing the steel at intervals is in rogue, and of stamping each ingot with special marks so that the consumer can ascertain from the company at any time every particular regarding the analysis and making of the piece. 
The gases produced in the coke ovens are used in the open-bearth furnaces, the other bye-products, namely coaltar and ammonia, being also collected. The ammonia is converted into ammouium sulphatc by neutralising it with sulphuric acid-which can be obtained from the pyrites separated from the coal in the preliminary grinding and washing processes to which it is subjested-and is principally exported to the United States, the West Indies, and Glasgow. The coal-tar at present finds a market in the States, at Montreal, and other points in Canada. Recently arrangements have been made with an English chemical company to locate at Sydney. The works are now in process of construction, and all the coal-tar produced will be utilised for the manufacture of the numerous products of distillation.

Canadian-made steel is largely exported to the United States, whence it returns to Canada in the form of rails and other finished products; but it is intended that this feature of the steel industry will shortly be transferred to Canadian territory. Sydney is extremely well situated as a seaport, being nearer to England than is New York, and, strange as it may appear, to the ports of Soutb America and South $A$ frica. ${ }^{9} \Lambda$ s far as geographical position is concerned, therefore, Sydney possesses many advantages, while the masterly and liberal way in which the iron and steel industry has been orgauised and developed points to a bright future for it in Canada. ${ }^{10}$

A new plant is heing erected near Nortl Sydney by the Nova Scotia Stecl Co., who have at present works at Ferrona,

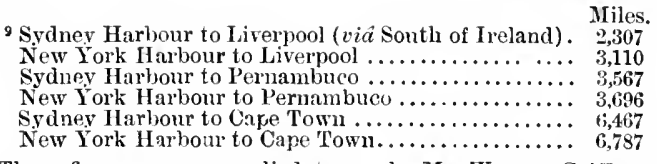

These figures were supplied to me by Mr. Watson Griffin, who obtained them from Captain W. H. Smith, R.N.R., Halifax. The distances from New York were compiled by the United States Counmission of Navigation.

${ }_{10} \mathrm{Mr}$. Watson Griffio, who kindly supplied me with material from which the above description of the Sydney operations was written, mentioned also that a leading Scottish iron and steel magnate told him that, everything considered, Sydney, in regard to raw materials, nearness to the market, and the excellent equipment it possessed, would be the finest steel manufactory in the world. Watson Griffin, "Ilominion Steel and Coal Co., Sydney;" Montreal, 1902. Watson Griffin, "The Front Door of Canada;" IIontreal, 1899. 
with a limited supply of ore near at hand. Hence they import largely from Newfoundland. Their steel works are at present at New Glasgow, but a new plant is under construction at Sydney. Their output, which is so!d almost exclusively in Canada, approximates 100 tons of pig-iron per day, and the same amount of steel. The Canadian Iron Furnace Co., of Montreal, bas recently acquired the iron deposits formerly belonging to the Londonderry Iron Co., and is reconstructing the works on the most modern plans.

Copper.-The production of refined copper can hardly be classed among the chemical industrics of the Dominion, as practically only the first stage in the extraction of the metal is reached, namely, the making of copper matte, which is exported to the United States to be refined. Copper ores occur in great abundance, and constitute one of the most important mineral resources of the country. These are distributed over large tracts in Ontario, Quebec, Nova Scotia, and New Brunswick. 'The deposits consist of native copper and sulphirles, the former confined principally to the Lake Superior region, the latter being more widely diffused, but notably in the Sudbury region, Ontario, where it occurs with nickel. The production of copper, other than the native copper near Lake Superior, is dependent for the most part on that of this latter metal. Some jdea of the advances made in the production of copper matte may be had from the fact that in 1891 the production amounted to $9,000,000 l$, while 190 l showed an outpnt of $41,000,000 l .^{11}$

Nickel.-The first diccovery of nickeliferous deposits was made in 1883 near Sudbury, in the district of Algoma, Ontario. The ore, which contains on the arerage about $2 \cdot 25$ per cent. of nickel, is roasted in heaps, and smelted in a Herreshoff water-jacket furnace, near the mine, into a copper nickel matte, the average composition of which is : copper, 26.91 ; nickel, $14 \cdot 14$; iron, $31 \cdot 335$; sulphur, $26^{\circ} .95$; and cobait, 0.935 . It is also said to contain some ounces of platinum to the ton. Previous to the discovery of nickel in this country, the French colony at New Caledonia contributed the world's supply of the metal. Now the International Nickel Co. controls the deposits in. Ontario and in New Caledonia, and has refining works at Hampden, N.J., in the United States. ${ }^{12}$

11 Statistical Year Book of Canada, 1901.

12 The French Société le Nickel, with works in New Caledoniz. and refineries in France, is not inctuded in this combination. 
A partial list of firms engaged in nickel production is given in the Appendix. Tne Frasch and the Mond processes are the principal methols of treating the matte, that from the Victoria Miues of the MIond Co. being shipped to Swausea for treatment in England. The Frasch process for the separation of copper and nickel is an electrolytic oue, and is being largely adopted here. ${ }^{13}$

Aluminium.-The extraction and refining of aluminium has in recent years, owing to the advent of electricity developed from cheap water power, become an important industry. At Shawinigan Falls, Qnebec, are situated the Canadian works of the Northern Aluminium Co., a subcompany of the Pittsburg Reduction Co., which also has two large factories at Niagara Falls, on the American side. 'The raw moterial, bauxite, is obtained from Alabama and Georgia, in the Uniter States. The process employed is the Hall ${ }^{14}$ process, and is a combined electrolytic and electric furnace one. The native aluminium hydroxide is first purified by mixing with sufficient earbon to reduce all impurities in it to the metallic state, the resulting iron, mixed witl: titanium and silicon, forming a slag after melting the mass in an electric furnace. An alternating current of low voltage is userl, and the purified alumina separates out above the slag in an almost chemically pure condition. The aluminis thus purified is then electrolysed in a bath containing cryolite at a temperature of from $850^{\circ}$ to $900^{\circ} \mathrm{C}$. The action of the current sets free aluminium and oxygen, the latter uniting with the carbon anodes to form carbonie oxide. The metal is run into rough ingots weighing $20 \mathrm{lb}$. each, and is stated to contain, on an average, $99 \cdot 5$ per cent. of aluminium..$^{15}$

The production at the Quebec works is probably 9,500 lb. per day, the value in 1902 bcing approximately $1,043,250$ dols. ${ }^{16}$ It may safely be said that the three works of this Company, between them, produce one-hali of the world's supply.

Lead and Silver.--'These metals are derived principally from the mines of British Columbia, but there are also deposits of galena along the shores of Lake Superior, the ore from which is sent to Niagara Falls, N.Y., for reduction.

13 U.S. Pat. 669,599.

14 U.S. Pat. 677,207, 677,208, 677,209, of June 25, 1891 .

$15 \mathrm{Dr}$. J. W. Richards in "Electro-Chemical Industry, Oct. 2902 .

${ }^{16}$ Ibid. (average value ol product is 31 cents per pound). 
The British Columbia ore is a high grade one, carrying from 200 to $300 \mathrm{oz}$. of silver to the ton, and is mostly smelted at Butte and St. Helena, Montana. No refinery for lead (on a large scale) has yet been started in Canada, though at Trail, in British Columbia, the Canadian Smelting Works have recently begun to produce commercial lead, stated to be of 99.9 per cent. purity, ${ }^{1 \overline{ }}$ by means of the Betts process, which is an electrolytic one.

The Hall Mlining and Smelting Works, whose Canadian headquarters are at Nelson, British Columbia, are smelting lead ores which are obtained in the Slocan and Kootenay Lakes. They employ blast furnaces, a considerable portion of the ore being first roasted in hand or mechanical furnaces and the product of the latter briquetted. The principal markets for the pig-lead are the Orient, England, and Canada, thongh the home market is somewhat bandicapped by the present arrangement of duties, which allows the importation of foreign corroded lead at a lower rate than that imposed on pig-lead. With a revisal of the duties, a greatly increased development, and revival of the lead and smelting industries, is anticipated. ${ }^{18}$

In 1894 the amount of silver exported, in ores, concentrates, or otherwise, was $629,655 \mathrm{oz}$., while in 1901 the quantity had risen to over $4,000,000$ oz. ${ }^{19}$ Despite these figures, the "Monetary Times," Toronto, of date Jan. 16, 1903, says, "The silver-lead production of British Columbia is severely handicapped by the adrerse competition of the United States, the European and Mexican products. The tariff is unfavonrable-a higher one would be quite beneficial to the industry."

Arsenic. - A not unimportant metal found in considerable quantities in Ontario is arsenic; the chief form in which it occnrs is arsenical pyrites (mispickel), which also contains gold. Its manufacture was begun by the Canadian Goldfields, Ltd., at their Deloro Mine, Hastings County, Ontario, in 1899. Attempts had been made, extending over the previons 20 years or so, to extract the gold from the ore fonnd there, and, after the mine had experienced some vicissitudes, the present company acquired it and obtained the rights (1896) for Ontario to the Sulman-Tweed patents (bromo-cyanide process), working it with only a modified degree of success for a couple of years, when the installation

17 Canadian Mining Rev., Marcl, 1?(0),

is Letter from the Business Maniger, Hik'I Mining and smelting Co., Nelson. B.C.

19 Statistical Year book of Canada, 1901. 
of improved machinery and the adoption of a combination of amalgamation and leaching with bromo-cyanide resulted in the recovery of arsenic from the mispickel concentrates. 'To accomplish this the concentrates are heated to a high temperature in specially constructed eylindrical revolving calcincrs, and the resulting impure arsenious oxide evolved is condensed in hermetically sealed brick cbambers.2" The crude arsenic is refined by sublimation, and contains from $99 \cdot 6$ to 100 per cent. arscnious oxide, the main impurity being silica in a finely divided condition. ${ }^{21} \mathrm{It}$ is exported chiefly to the United States, where it is used for making "Paris Green," \&c. The output has increased from $113,477 \mathrm{lb}$. in 1899 to $1,347,000 \mathrm{lb}$. in 1901.20 In time, and with proper development, Ontario should be able to supply the entire demand for arsenic on the continent of Anierica.

Autimony.-This metal might almost be said to occupy the position of a by-product in the extraction of gold. At Rawdon, in Nova Scotia, the ore (stibnite) is auriferous, and from 1898 to 1901 no refined antimony was produced, the stibnite being mincd for the salie of its more precious contents..$^{22}$ It is also found in Quebec, and receut reports indicate deposits of ore in several localities of Ontario and British Columbia. The output in 1891 had fallen to 60 dols. In 1902 the refining of the metal was renewed.

Gold.-Gold is mined to a small extent in Ontario, in in Nova Scotia, and Quebec. Gold deposits are aiso found in the Kootenay district, B.C., in Cariboo, B.C., and in the Yukon. In the Rossland district the ore is a cupriferous pyrrnotite under a diorite cap, and from Trail on the Columbia River, where the ore is smelted, the gold-copper natte produced is shipped to Montana for refining purposes. There is also a smelter at Nelson for the ore of the Hall mine. The Yukon territory covers in a general way

20 C. Kirkegaard, in Eng. and Mining J., Jan. 31, 1903.

21 Bureau of Mines Report, Ontario, 1901.

${ }_{22}$ Assays of two ores give, according to the Nova Scotia Mincs Report, 1901 :-

\begin{tabular}{|c|c|c|}
\hline- & I. & II. \\
\hline 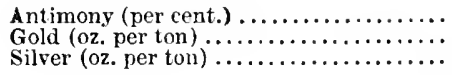 & $\begin{array}{r}45 \cdot 75 \\
2 \cdot 48 \\
0 \cdot 10\end{array}$ & $\begin{array}{r}18 \cdot 21 \\
0.23 \\
0 \cdot 13\end{array}$ \\
\hline
\end{tabular}


the district north of Cariboo, sisuth of the Arctic Ocean, and lying between the Mackenzie River and the AlaskaCauada boundary. Gold las been known to exist there sinse 1864 , and has been worked intermittently since 1873 . Forty Milc River, a tributary of the Yukon, was discovered to carry coarse gold in $18 \$ 6$, and, 10 years later, what is known as the Kilondike was found to contain gold also. It was first discovererl on Bonanza and Elilorado ereeks ${ }^{23}$ : the news of this discovery spread far and wide, and active prospecting was the result. There are about 1,400 miles of Cinadian Yukon streams, on all of which gold cau be found. Mr. Ogilvie, former Canadian commissioner in the Yukon, estimates that an area of 125,000 square niles is gold bearing. ${ }^{24}$ The former difficulties of reaching the Yukon have now been overcome; a telegraph line has also been laid by the Canidian Government from Skagway, on the coast to Dawson. The gold is found and worked in the gravel deposits of the villeys and on their adjacent slopes, and it has been estimated that gold to the value of $95,000,000$ dols. will be produced from these deposits in the next few years. 25

The gold fields of Nova Scotia occupy the entire Atlantic coast line, and contain gold in combination with sulphides and arsenides of iron, but mostly in the free state. The table giren in the next column will best convey the output of gold from Canadis and its distribution..$^{\circ}$

The goll production fur the Yukon in 1902 was $12,018,551$ dols.; according to the United States Mints it was $14,525,275.2 i$

\begin{tabular}{|c|c|c|}
\hline & 1892. & 1901. \\
\hline 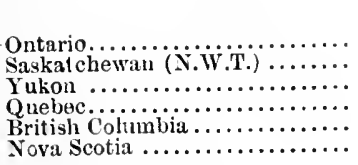 & $\begin{array}{r}\text { Dols. } \\
7,118 \\
98,006 \\
0,987 \\
12,987 \\
399,525 \\
389,965\end{array}$ & $\begin{array}{c}\text { Dols. } \\
243,022 \\
15,000 \\
12,500,000^{28} \\
3,000 \\
5,596,700 \\
604,500\end{array}$ \\
\hline Total............ & 907,601 & $24,463,2 \pm 2$ \\
\hline
\end{tabular}

23 "Official Guide to the Klondike," by William Ogilvie.

24 Ibid.

25 Report of the Canadian Commission in the Yukon.

to Statistical Year Books, 1992-1902.

2) Letter from Hon. Clifford Sifton. Hinister of Interior Ottawa.

23 Letter from IIr. B. E. Walker, General Manarer, the Canisdian

Bank of Commerce. 


\section{III.-The Leather and Tanning Industries.}

The manufacture of leather occupies quite a prominent position in Ontario and Quebec, the industry having greatly developed during the past few years. There are from 18 to 20 large establishments in operation, and fully 20 small ones. Bark, chrome, and combination tanning metheds are employed, the spent bark being utilised as fuel in specially constructed furuaces. Though the United States may be said to lead the world in the extent of the leather produced, the quality of the Canadian product cannot be surpassed in heavy leathers for common goods. Light leatbers, too, have made very ereditable progress; also chrome kids and classes of bag, case, and trunk leathers. Mueh of the Ameriean patterned machinery employed, and formerly imported, is now being manufactured in the Dominiou, such as bark mills, fleshing machines, glazing jacks, measuring machines, and leather presses. As compared with a decade ago, the value of the leather preduced in the country may safely he sajd to have increased one half.

\section{IV.--Sulphuric Acid, Acetic Acid, Wood Alcohol, Charcoal, and Ammonia.}

The manufacture of eommereial sulphurie aeid has not yet been developed to the extent that the quantity of sulphur found throughout the Dominion would justify. There is enough sulphur in Canada to supply the entire home market with acid and even to develop a considerable export trade. Only a few firms, however, are engaged in the trade, and a large portion of their product is used in the refining of Canadian petroleum, some fire million pounds being annually consumed for this purpose. Quebee, Ontario, and British Columbia are each represented in the acid industry. The Lake Superior Power Co. employs the sulphur obtained in the smeitiug of nickeliferous ores in the manufaeture of sulphite pulp, but only utilises it as required for its own industrial operations. It is probable that the construction of electrolytic lead smelters will lead to the sulphur dioxide obtained from the galena being made into sulphuric acid, as is done at the Electric Lead Reduction Co.'s works at Niagara Falls, N.Y., where, it is stated, the sulphuric acid produced yields a financial return sufficient to cover the entire cost of the process.

By the destructive distillation of wood, acetic acid, woodalcohol and charcoal are obtained; hence Canada, with its enormous supply of wood of all kinds, should be able to 
take a prominent place in the production of acetic acid and wood spirit. At the present time the residual charcoal from the retorts does not find a ready market, owing to the comparatively higb rates for transport as compared with other fuels, weight for weight. The outlook in this direction is, however, brightening. Among the firms engaged in this manufacture might be mentioned the Standard Chemical Co. - with plants at Fenelon Falls, Deseronto and Longford, Ontario, and Conkshire, Quebec-and the Canada Paint Co., Montreal and Toronto. Very keen competition has to be faced in this connection with the United States, as a combination of some 175 manufacturers practically controls the market. The crude acetate of lime produced in the distillation process is converted into acetic acid, some of which is sold for dye and colour making purposes, while a considerable portion is exported to Europe and Australia.

The wood alcohol, obtained at the same time as the acetic acid, supplies the home market and is also exported largely to great Britain, France, Germany, Holland, Japan, and Australia. It may be of interest to know that timber is imported from Canada by makers of wood-alcohel in the United States..$^{29}$

\section{V.- Soap and Glycerin.}

Soap.-The soap industry in Canada is growing rapidly ; at the present time some 15 large concerns are in operation, employing in all about 2,000 hands. A branch of the wellknown firm whose headquarters are at Port Sunlight, near Liverpool, was recently started in Toronto, with an annual capacity of 10,000 tnns. Their products are similar to those made at their other works, and their raw materials are procured from Africa, the United States, and locally (tallow). They own islands in the Pacific from which they import cocoanut oil.

Most of the other firms mentioned in the Appendix are also manufacturers on a large scale and produce all grades, from the cheapest textile and laundry soaps to the finer qualities of toilet soaps. Great advances have taken place in the industry during the past 10 years, particularly in the making of the latter. The same system of manufacture obtains as in England. The raw materials are mainly cocoanut oil, palm oil, and tallow, the first two in a large

${ }^{29}$ Mr. Webster, of the Standard Chemical Co. 
measure superseding the last mentioned. The market for Canadian made soap is limited, the home market is supplied and a large export trade is done with the West Indies and Australia. The competition of the United States is felt more than that of lingland or France. In 1902 the value of the soap produced was approximately $3,000,000$ dols. ${ }^{30}$

Glycerin.-This necessary by-product in the manufacture of soap is refined in some cases by the producers themselves; uthers sell it to firms engaged more particularly in the refining trade. Among these might be mentioned the St. Henri Chemical Co, of Montreal, who bny waste lyes from the soap manufacturers, recover the salt from the lye, refine the glycerin and sell to the makers of nitroglycerin. The capacity of these works is $10,000,000 \mathrm{lb}$. of waste lye yearly.31

\section{VI.-Refined Chemicals and Drugs.}

One is reminded forcibly, after writing the heading to this section, of the "Suakes in Ireland" story, and, indeed, the classical remark rccorded on that occasion inight almust be said to apply with equal force to the refined chemicals produced in the Dowinion. Messrs. Lyman Bros. and Co., of Toronto, however, are conspicuous in having their own laboratories, in which are made some 150 salts, acids of phosphorus, syrups, tinctures, and flavouring extracts. Most of the raw materials are imported. The scope of the business is increasing yearly. The production of chemicals in 1892 amounted to 37,000 dols., and last year had increased to 50,000 dols. The small demand for pure chemicals is mainly accountable for the lack of local manufacturers, the market being necessarily a small one, and most buyers of pure chemicals for laboratory uses are apt to demand articles of the make of one or other of the large and old-established German or English houses. One can hardly doubt but that the Canadian maker must desire a higher tariff on imported ntaterial. Within the last year the Liquid Carbonate Co. - and liquid carbon dioxide is made in Cavada, and used largely in the manufacture of aërated waters-have been making Epsom salts and Glauber's salt as a by-product, while pepsins and phosphates, mainly for medicinal purposes, are now produced by the William Divies Co.

so Mr. Knight, of the Sunlight Soap Co.

3r Letter from the President of the Company. 


\section{VII.-Fertilisers.}

IIineral phosphates, in the form of apatite, are found in the Ottawa Valley, Ontario, but the deposits have not been worked for several years. About 1891, in which year the phosphates mined were valued at 50,000 dols., a falling off began in the output of this mineral, which has continued up to the present time, the amount now nined being hardly worth recording. This state of affairs has been brought about mainly by the large supply of easily-worked phosphates found in Florida and Carolina, U.S.A., much of which is obtained by dredging. It may be mentioned, however, that a certain amount of apatite is made use of in the Province of Quebec by the Buckingham Electric Reduction Co., who manufacture phosphorus therefrom..$^{32}$

Sulphate of ammonia is manufactured at the works of the Dominion Irou and Steel Co., Sydney, N.S., whose products are supplied to dealers and others engaged in the fertiliser bnsiness. The ammoniacal liquors of the Quebec, Ottawa, and Toronto Gasworks are worked up at the latter eity by the Michigan Ammonia Co. ${ }^{33}$ In Montreal, one firm, at least, makes sulphate of ammonia, and at one time the gasworks there utilised their own liquors for its production. Latterly, however, the gas liquor was exported, to be dealt with by a firm in the United States.

Quite a number of other fertilisers are produced in the Dominion from refuse matter, such as blood, tankage, bones, and offal, besides natural phosphates. Ontario, New Brunswick, Qutbec, Nova Scotia, Prince Edward Island, and British Columbia, all produce fertilisers, more or less. ${ }^{34}$

\section{VIII.-Coal-Tar and Asphalt.}

Very little tar distillation is carried on in the Dominion, owing to the tar produced in the gasworks being too thick for treatment with any degrce of success. It is mainly used for saturaturing paper, which is employed largely as a waterproofing material by builders. Some is boiled down into pitch, but fully one half of the tar produced is exported to the United States. There is a small distilling plant at Hamilton, Ontario, which, the writer understands, is at

32 Minerals of Quebec; published by the Prov. Government.

33 Letter from Mr. Macfarlane, Chief Analyst to the Inland Revenue Department.

3. Inland Revenue Bulletin, No. 81, 1902.

P 7293. 5 . 
present the only one of its kind from which coal-tar oils are produced in Canada. ${ }^{35}$

Asphalt.-Asphalt occurs naturally in several varieties as albertite, found in King's and Albert Counties, N.B., and as maltha, one of the stiffer petroleum compounds, which is not of much importance, however, being almost too hard for use in street paving. Up to 1898 , albertite was employed in gas-making, and much of it was shipped to the United States, but the original supply is now exhausted.

\section{IX.-Calcium Carbide, Carborundum, and Graphite.}

Calcium Carbide.-The production of this substance on a manufacturing scale dates back only to the year 1891, when Mr. T. L. Willson, of the Willson Aluminium Works at Spray, N.C., accidentally obtained carbide whilst trying to reduce lime hy carbon in the electric furnace. Instead of metallic calcium resulting-which was to be employed in prepuring aluminimm-a hard, almost black, substance was obtained which reacted violently with water, giving lime and an inflammable gas clearly recognisable as acetylene. The author was privileged, through the courtesy of Lord Kelvin, to have at one time in his possession some pieces of the first carbide made by Mr. Willson at Spray. Acetylene being a powerful illumiuating agent and readily obtained from carbide, the development of the carbide industry on a commercial scale followed this discovery as a natural consequence. The industry bas progressed by leaps and bounds during the past decade, in Europe eren to the extent of orer-production. ${ }^{36}$ Two carbide works are in operation in Canada, usine water as their source of power, namely, the Willson Carbide Co., at St. Catharine's, Ontario, and the Ottawa Carbide Co. The Union Carbide Co. ${ }^{37}$ of Chicago, which utilises 13,000 horse-power in all and has an immense establisbmert at Niagara Falls, N.Y., has contracted for a large amount of power for a new plant at Sault Ste. Marie, Ontario, for the manufacture of carbide. $^{38}$ Another important prospective company is the Shawinigan Carbide Co. of Shawinigan Falls,

35 See Section II., Iron and Steel.

36 Italy alone possesses enough earbide plants to supply the whole of Europe. Dr. J. W. Richards, in "Electrochemical Industry." Sept. 1902.

37 Capitalised at $6,000,000$ dols. On the American side of the river.

38 “" Electrochemical Industry," Dec. 1902. 
Quebee, ${ }^{39}$ the works being now in the course of construction. The process of mannfacturing consists in fusing together burned lime and ground coke in the eleetric furnace; the temperature required is not so high as that needed in other operations for which the electric furuaee is employed, notably the making of carborundum and graphite. The reation taking place in the furnace resnlts in a transference of the oxygen of the lime to a portion of the carbon with the formation of earbon monoxide and carbide of calcium.

The present market value of carbide $(61 \text { dols. per ton })^{40}$ affords considerable profit to its manufaeturers, and the increasing popularity of acetylene as an illuminant ensures a brighter future for the industry. In Ontario several towns have already had acetylene installed for house and street lighting, the gas being generated at a central station and distributed in pipes to the consumers. ${ }^{41}$ At the generating station the gas is purified by a special process before use, which obviates all the disadvantages inseparable from the employment of small generators-automatic or otherwiseby individuals, who in most cases bave neither the time nor the scientific skill necessary for the proper production of the gas, simple as it may appear at first sight.

Carborundum.--Ten years ago the very name "carborundum "was unknown; it is due entirely to the adrance made in the development of electrical power, obtained from the immense waterfalls of the Ameriean Continent, that this as well as other materials are now in daily use throughout the world. Although deposits of corundum itself are found in Eastern Ontario, the artificial earbon silicide has practically supplanted the natural product as an abrasive agent. 'The history of carborundum may well be likened to that of carbide, its discovery being aecidental. A full aecount of this interesting substance will be found in a paper by the Chairman of the Liverpool Seetion (Dr. Kiohn) in 1897 (see this Journal, 1897, 863).

The Canadian works of the Carborundum Co. are comparatively small, only operating 200 horse-power. The factory, however, supplies the Canadian market, thus avoiding the payment of duty. The writer is informed by

39 Capitalised at $1,000,000 \mathrm{dols}$.

40 Untario Mines Report, 1901.

41 Worked under patents held by the Burzess Gas Process Co., Canadian $P_{\varepsilon 1}$. 73,040, Sept. 10, 1901; Eng. Pat. 211, Jan, 3, 1901; Amer. 1'at. 701,995, June 10, 1902. 
Mr. Acheson that most of the Canadian product is exported to Scotland, to be used there in finishing granite. The estimated cost of the crude erystals is $2 \cdot 5$ cents per pound, that of the treated powder, $4 \cdot 5$ cents per pound, while the selling price averages 9 cents per pound. ${ }^{42}$

Graphite.-Though no company for the manufacture of graphite has yet been capitalised in Canada, ${ }^{43}$ the production of it by the Acheson process is carried on to a small extent in the Canadian branch of the Carborundum Co. at Niagara Falls. The formation of the "skeleton" crystals suggested making use of the decomposition of carborundum for making graphite itsclf. The inventor's patents include the production of graphite in the form of pure electric-light carbon, by subjecting impure carbon to a high temperature for a sufficient length of time to volatilise the impurities; ; $^{\text {H4 }}$ the conversion of carbon into graphite by mixing with it such metallic oxides as would be capable of forming metallic carbides, to be subsequently decomposed $;^{45}$ the conversion into graphite of such natural carbonaceous material as contains, uniformly intermixed through it, metallic oxides sufficient to prodnce carbide, and thence graphite. ${ }^{46}$ These processes throw considerable light on the scientific principles underlying the formation of this substance. ${ }^{47}$

\section{X.- The Cement and Plaster Industry.}

The manufacture of I'ortland cement is mainly confined to Ontario, though owe establishment-the Crescent Cement Works-is situated at Longue l'ointe, in the province of Quebec. In Ontario there are some 14 companies, and eight factories in operation, and throughout this Province are found the necessary raw materials (clay and marl) of an excellent quality. The development of the industry has been rapid, and has all taken place within the past few years. The most improved method of proccdure is as follows : the marl is thoroughly mixed, mechanically, with water into a thin paste, and the same operation is performed with the clay. The two fluids are mixed thoroughly in the

\footnotetext{
42 U.S. Pat. 542.982 of July $23,1895$.

43 Letter from Mr. Achesoll.

44 U.S. 1'at. $5+2.982$ of July $23,1595$.

t5 U.S. Pat. 568,323 of Sept. 29, 1896, and No. 617,979 of Jan. 17, 1599 .

46 U.S. Pat. 645,285 of March 13, 1900.

47 Electrochemical Industry, Vol. I., No. 2.
} 
required proportions, and in a pasty condition are pumped into rotary steel calciners, abont $70 \mathrm{ft}$. in length and $6 \mathrm{ft}$. in diameter, set at a slight angle to the horizontal. These rotary ealciners are the great feature of the Canadian cement plants. This form of kiln is originally of English origin, but has only been brought to its present effective condition since its introduction to this country. In the interior of the kiln are "channel-irons" running from $\in$ nd to end. At the lower end fuel is introduced in a particnlar manner, and the burning gases pass through the entire length of the kiln, and are allowed to escape at the upper extremity. At this latter end is introduced the "slurry" of the mixed ingredients, which becomes drierl and finally calcined in the slow passage from one end to the other. The revolving irons carry the "slurry" up with them as they rise, and on reaching the top it falls, under the action of gravity, through the burning gases, being subjected at the hottest part to a temperature of $3,000^{\circ} \mathrm{F}$, when combination takes place between the constituents of the fused mass, and the resulting " clinker" emerges into the vessel destined for its reception. The drying and calcining is thus performed in one operation, and no preliminary pressing of the material into bricks is required. ${ }^{48}$ At the works of the National Portland Cement Co., recently erected at Durham, Ont., a great saving of time is effected by cooling the clinker in vessels drawn by an endless chain through a stream of water below the ground level. After cooling in this manner it is ground to a fine powder, and packed in bags or barrels ready for use. The whole operation by this process occupies only eight hours, a period of time which will be appreciated by all aquainted with the older methods. At Durhan the raw materials are brought from the natural deposits, which are close at hand, calcined, cooled, ground, and packed by means of a continuous series of mechanical conveyers, froin one part of the cstablishment to the other. This company has another plint in course of erection at Hull, P.Q., on the Ottawa River, which is intended to supply the Eastern Canadian market.

Several articles have appeared lately in the public press, ${ }^{49}$ pointing out that a possible over-production of cement may be the result of the numerous liarge concerus which are 1903.

48 The Portlind Cement Industry: "Queen's Quarterly," Jan.

49 "The Globe," Toronto, Mareh, I943, aut sther papers. 
already in operation, or are about to be started. Whether or not this will take place in the inmediate future depends, natually, on the general prosperity of the country and the consequent demand for building materials. Certainly cement has gained considerable reputation as a substitute for stone, as can be seen by the extent to which it is made use of by architects. It can be readily moulded into any form and may then be dressed to represent the natural article. Whether it can cver oust stone or brick from their present position depends, not only on its comparative cost, but on the quality of cement put out by manufacturers. One case of a collapse due to an admixture of a single bag of inferior material and the whole fabric of the cement industry, as supplying a substitute for the older building materials, will be in danger of a similar fate. The total output of Portland cement in 1902 was valued at $1,028,618$ dols. ${ }^{50}$

Gypsum is found in considerable quantities in Nova Scotia and New Brunswick. At Windsor, N.S., there are immense deposits; the beds found in the vicinity of Hillsborough, N.I., are, however, very large and of great purity, and form the basis of the most exteusive operations. ${ }^{51}$ It is also found in Ontario, and plaster works are located at Paris in that province. In 1901, active operations were begun at Gypsumville, Manitoba. The industry, however, is principally located in New Brunswick. Drawbacks in the way of freight charges, inadequate shipping facilities, and the competition offered by manufacturers of plaster of Paris in the United States, kept the industry from dereloping until the Intercolonial Railway was opened and the increased duty on American plaster imposed, when the New Brunswick plaster, quarried and prepared at Hillsborough, came to be firmly established on the Canadian market. In manufacturing plaster of Paris, the stone is first dried in the air and ground-not burned in lumps, as is still done to a considerable extent in England and on the Continent of Europe -and the pulverised material subjected to a process of calcination in kettles, of a capacity of 60 barrels of $300 \mathrm{lb}$. of the calcined plaster, furnished with lids and stirring arms which keep the material in constant motion. When the required temperature has been reached $\left(285^{\circ} \mathrm{F}\right.$.), the

${ }^{50}$ Geological Survey of Canada: Mineral Products, 1902.

51 Geological Survey of Canada: The Mineral Resources of New Brunswick, 1899. 
plaster is removed and packed in paper-lined barrels for market. Analysis of the Hillsborough gypsum sliows it to contain $99 \cdot 88$ per cent. $\mathrm{CaSO}_{4}{ }^{52}$ The principal narkets for plaster of Paris are Canada, the United States, and South Africa, while the crude gypsum is exported largely to New York anil other portions of the States, being used for making plaster for walls and ceilings. ${ }^{53}$ According to the Geological Survey Reports for 19192, the gypsim produced in Canada during that year amounted to over 332,000 tons, valued at 356,317 dols.

\section{XI.-Curbohydrates: (a) The Refining of Sugar; (b) The Beet-Sugar Industry.}

Refining of Raw Sugar. - The recent remarkable developments in the production of sugar from beets in Ontario and Southern Alberta have rather minimised the importance of the refining of imported sugars in the Dominion, and there seems little reason to doubt that the beet-sugar industry will continue to progress, as will be seen from the sequel. Statistics show that, during the last decade, cane sugar has increased in production about 200 per cent. Judging from pres?nt appearauces, and allowing for some slight tariff alterations, the itucrease in Canada should soon be in proportion to that of other countries. ${ }^{5-4}$

Raw sugar is inported from Cuba, the West Indies, Javi, Manila, the Brazils, Mauritius, and the Continent of Europe. The most improved machinery and processes are employed, refined sugars and syrups being the staple products.

Belgium supplies to Canada the largest proportion of sugar, the imports from that country amouuting in 1901 to $127,93 \mathrm{l}, 553 \mathrm{lb}$; from Germany in the same year $83,941,290 \mathrm{lb}$. entered the country, the total imports being $336,694,833 \mathrm{lb}$., valued at ciose on $8,000.000$ dols. ${ }^{53}$

Beet Sugar.- The most interesting point connected with the sugar industry is the remarkable way in which the production of sugar from betts cultivated on Canadian suil has become, in the past few years, an important factor in

${ }^{52}$ Analysis by A. A. Breneman, of New York, in Mineral Resources of New Brunswick, Geological survey of Canada, 1899.

53 Letter from the Mlanager, Albert Manufacturing Co,

is Letter from Mr. D. $\mathrm{A}$. Gordon, President of the Wallaceburg Sugar Co.

${ }_{55}$ Essay, Mr. Read, Eniversiry of Toronto. 
the country's progress. As far haek as 1872 the Dominion Government sent a special agent to Europe to make a study of the industry. A bounty of 25,000 dols., afterwards increased to 70,000 dols., was offered by the Quebec Government in 1875 to the first successful factory to be established in a situation approved by the Government. This led to the establishment of a company, known as the Union Sucrière du Camada, which, in 1881 , ereeted the first of four proposed factories at Berthierville, Que. ${ }^{56}$ This establishment was unsuecessful and only operated for a few days, mainly owing to the failure of the beet erop. After passing into other hands the plant was bought by an American company and removed to Eddy, New Mexico. ${ }^{5-}$ Another company was, in the same year, organised at Farnham, P.Q., not far from Montreal, which, after oome vicissitudes, did not deem its success sufficient to warrant a continuation of its operatious, so sold its plant to a company at Rome, N.Y., in 1897. A third company, known as the Pioneer Beet Co., started operations in 1881, at Coatieook, P.Q. 57 and was successful in part, receiving a subsidy of 35,000 dols. from the Govermment, but it, too, elosed its doors in 1883 . The eanses to which these failures may be attributed were lack of capital and enterprise, and the indisposition of the farmers to cultivate beets. The Agrieultural Departments of the Provincial Gorernments, however, eontinned experimenting with various kiuds of beets and studicd the conditions most favourable to their successful growth. For some years past the Ontario Agricultural College at Guelph has, as a consequence of the excellent resulis obtained at their experimental stations, been carrying on an edueational eampaign among the farmers of the prorince. As a result of this the quality and tonnage of beets now grown in different parts of Ontario surpass those of many American States. The elimate of this province, with its sunshine and long autumns, is peculiarly favourable to the cultivation of the beet, which takes about four months and a half to reach maturity. It requires, however, to be demonstrated to the farmers that the cultivation of beets will pay them better than other land produee before the requisite supply of suitable naterial will be obtained. That profits are large can be gathered

\footnotetext{
${ }^{56}$ Report of Dominion Government on beet sugar manufacture in Canada.

${ }_{57}$ Letter from the manager of the Drescen Sugar Co., Ontario.
} 
from the fact that wheat yields in Ontario 15 dols. an acre per annum, oats, $9 \cdot 74$ dols., and beets for sugar, 60 dols. In the last case the cost of production is necessarily large, owing to a greater anount of labour being required, but, all the same, the profits to the farmer should, with skilful treatment, be at least 30 dols. per acre per annum. The beet tops are of value as a fertilising agent owing to the salts they contain, and find a use also as a food for cattle. In 1901 beets were grown-under instructions from the Agricultural Department-in 15 districts of Ontario, and the average yield per acre was over 17 tons of a high quality of beets which gave an average of 15.6 per cent. of sugar of an average purity of $87 \cdot 7$ per cent. All this points to a great future for Ontario as a sugar-producing country ; this important fact has been fully realised by the Provincial Gorernment, which bas offered a bounty of 275,000 dols. for three years, ${ }^{53}$ to be distributed among factories according to the amount produced. Four companies have been organised lately, namely, the Wiarton. Beet Sugar Co. (capital 445,000 dols.), whose works are situated on Lake Huron, with a capacity for treating 350 tons of beets per day; the Dresdell Sugar Co., capacity 600 tons; and the Ontario Sugar Co., at Berlin, the last with a capital of $1,000,000$ dols.; each of these companieshas received a bonus from the town where it is situated, averaging 28,000 dols. The capitalisation of a company engaged in this industry depends entirely on the size of the plant, a general estimate of 1,000 dols. per ton of beets per day may be considered a fair calculation of what rould be required.

Beet sugar fartories have also been established in Alberta, in the Norllh-West Territories of Canada. Since 1898, an area of about 300,000 acres has been made productive by means of the irrigation system of the Canadian North-West Irrigation Co., and a portion of this area has been utilised for beet cultivation, principally by the Mormon settlers. The most important factor is now in conrse of construction at Raymond, south of Letbbridge, on the Canadian Pacific Railway. The capital of this Company is 1,000),000 dols. The area intended to be planted with beets is 3,000 acres, and the daily capacity of the factory will be 400 tons of beets per day. The only difficulty which the industry is encountering in the north-west is the scarcity of labour. ${ }^{59}$

58 I Edw. VII, cap. 11, 1901.

39 Letter from Manager of works at Raymond. 
This is due partly to the scanty settlement of the country, and partly to the superior attractions of the mining regions, which are situated at no great distance.

A plentiful water supply, lime, and a source of power, are necessary for the profitable prosecution of the industry ; all this has been carefully considered in locating the factories eun merated above, steam power being employed for pumping and the working of all machinery. There is room for many more factories in the Dominion; according to Dr. A. B. Shuttleworth, Chief Agrieulturist to the Ontario Sugar Co., whose name is indissolubly connected with the development of beet cultivation, it would require over 30 refineries of 600 -ton capacity to supply the lome market alone. ${ }^{60}$

The working season of a factory runs for about 100 days, operating continuously. The cost of the sugar is from 3 to $3 \frac{1}{2}$ cents per lb. and the profits to the makers are estimated at 50 cents per ton of beets used. This would mean that in a factory of 500 tons capacity, working for 1 ino days, the profits would amount to $25,000 \mathrm{dols}$.

The scope of this article does not allow of auy detailed consideration of the working process by which the sugar is extracted from the sliced beets and crystallised. New processes are being employed for utilising the residual molasse3. This is treated for the recovery of the sugar in some part, and also for the production of alcohol by fermentation. An American company in 1901 produced 915,000 galls. of alcohol in this way, of a quality considered to be quite equal to the grain product. Another new process is that of the manufacture of syrup from the beet instead of sugar; 40 galls. of this can be obtained from a ton of beet, which, at 30 cents a gallon, means a return of 12 dols. per ton of material nsed, while the product in sugar yields ouly from 7 to 8 dols. per ton of beets. The beet pulp refuse is also being largely used as a food for live stock, for which purpose it is extremely suitable owing to its nitrogen contents. In this connection a new process has been introduced for drying the pulp, which entails an expenditure of 5 dols. per ton, but, as the dried pulp is sold at $6 \cdot 25$ dols. per ton, a clear profit of $1 \frac{1}{4}$ dols. is thus secured to the manufacturer. ${ }^{61}$

60 Bertin News Record, Nov. S, 1902.

61 In the above I have drawn largely from an essay on the beet. sugar industry by Mr. E. R. Read, a fourth year student in the Department of Political Science, Univer'sity of Toronto, who kindly placed his papers at iny disposal. Also from Dr. Shuttleworth's article in the "Berlin News Record." 
The production of sugar from Canadian grown beets is a new and rising industry which offers great scope for some co-operative arrangements between the companies and the farmers. It should give an impetus to agriculture, afford employment to thousands of unskilled workpeople, and, as an important industry, be a lasting benefit to the country. The following communication, dated March 6, 1903, from Mr. Genrge Elsey, manager of the Dresden Sugar Co., conveys some idea of the position of the industry at the present moment and its possible future :-

"At the present time there are four fictories which operated this last season, and, from what we are able to learn, the results were as satisfactory as could be expected under the existing conditions, that is, the rainfall last summer damaged the beet crop from 50 to 60 per cent., both in the United States and in Canada. The balance of the crop, on account of wet weather, cost considerably more to raise than what was necessary. It was unfortunate that this should occur in the first season that the factories were started in Canada as it was very disappointing, but most of the farmers have told us that they were surprised at the amount of rain the bect would stand, and in several instances where they could harvest the beet crop, the corn and other crops were ruined. After we have had a seasonable year, and it will be dewonstrated to the farmers that there is more money in raising sugar beets than any other crop that gruws, the four factories now in existence will get their supply of beets within hauling distance of the factories. . . Our farmers know well that the Michigan farmers obtain about a dollar a ton more for their beets than they do, and they also understand that it has cost as much in money and labour to raise a tor of beets in Canada as it does in Michigan or any part of the United States. They therefore feel dissatisfied, and are clamouring for more money, which the companies would be glad to pay if they could sell their sugar for the same price as the American Beet Sugar refineries. The difference between the two markets to-day is $1 \cdot 10$ a 100 . The present Canadian sugar tariff is such that it would not allow any more sugar refiueries to be built in Canada. The companies that are already here have the experience of what this tariff can do. It allows sugar that has been refined in the United States to be shipped in here and undersell Canadian refined sugar, which means a loss to the refineries and to the Canadian people. It allows raw beet sugar to be im- 
ported at a price that will prevent the farmers from taking hold of the beet industry as they should. Canada is sending to Germany and other foreign countries about $1,00 c, 000$ dols. per month for raw heet sugar, and the naturally yearly increase of consumption is abcut eight per cent., so that the future of the sugar beet industry, under a proper tariff, would be a lasting one and a great benefit to the farming community."

\section{XII.-Natural Gas and Petroleum.}

Natural Gas.-The existence of naturai gas in Ontario. was first aiscovered in 1889 , being found in two well-defined. areas, as the Essex county field and the Welland county field. It is chiefly near Buffalo, on lake Erie, and near Windsor, Ontario, that the largest supplies are met with, though practically it may be got in mearly any part of the Niagara peninsula in small quantities. In 1901 there were $158 \mathrm{wells}$ in operation, and 368 miles of piping were needed to distribute the gas. Much of the gas produced in Essex county was formerly led across the river to Detroit by pipe lines, but on representations made by the peopleof the Essex district, to the effect that the supply of gas was not sumpeient for home consumption, the Ontario Government passed an Order in Conncil, in October 1901, prohibiting the gas from the Essex field being exported to. the States. None of the product of this natural gas field is therefore now being sent across the Detroit river; it is, however, still exported from the Welland field to the Ameriean side of the Niagara river, chiefly to Buffalo, N.Y. It may be mentioned that the laudowners on whose farmsthe wells are loeated get their gas free in addition to being paid for the use of their land.62 The value of the gas produced in Ontario during the last ten years shows considerable fluctuations, being somewhat less in 1901 than in the previous year, due, no doubt, to the Goverument prohibiting its export. ${ }^{63}$

Petroleum.-This is one of the chief mineral products of the Dominion, thongh as yet the output is not sufficient to meet Canada's needs. The principal seat of the industry is at present in Ontario, where commercial quantities are found in the counties of Kent and Lambton. In the former there are two oil fields, one at Oil Springs, extending over 1,200

62 Report of the Burean of Mines, Ontario, 1902.

63 Statistical Year Book of Canada, 1901. 
acres, and the other in the Petrolea district, 20 miles long by 2 wide. ${ }^{61}$ In Lambton county the industry dates back to the year 1862. Petroleum is also found in Quebec, Nora Scotia, and New Brunswick, and boring operations that have in recent years been carried on at $\Lambda$ thabasca, near Edmonton, in the North-West Territory, point to a likelihood of that part of the country contributing largely to the future supply of mineral oil.

Tine industry is now one of the most highly organised in the Dominion; the system of drilling and pumping now used-the "jerker-line" system-enables a well fielding from eight to ten gallons a day to be profitably worked. This system has gained for itself a world-wide reputation; it is used in Galicia, Russia, Afghanistan, Burmah, India, Italy, France, California, and Australia. Its advantages are numerous: a central engine can operate a large number of wells ; on one property near Petrolea, 233 wells, scattered over an area of 400 acres, are worked by a single engine. It is estimated that to sink a well of about 500 feet in depth costs only 125 dols. $^{65}$ In 1900 , there were approximately 10,000 wells in operation, yieldiug on an average 71 barrels of oil each.

The refining side of the petroleum industry is largely in the hands of the Imperial Oil Co., ${ }^{66}$ which some years ago absorbed several other concerns, and of the Canadian Oil Refining Co. The plant of the former at Sarnia bas a capacity of 60,000 barrels of crude oil per month, aud the market for their products reaches from Halifax to Vancouver. Many of the bye-products of the refining process find a market in England and in Spain. 'The latter company have erected an up-to-date plant at Petrolea, on the site of one which was iu operation some years ago, where all the products will be manufactured that modern science shows can be obtained from petroleum..$^{i-}$ Improvements in methods of retorting have recently led to a considerable quantity of the crude oil being used for gas making, $3 \frac{1}{2}$ million gallons being an estimate of the amount so employed. ${ }^{67}$

64 The oil is found at depths varying from 370 to 400 feet.

65 This, and much of what is given here on natural gas and petroleum, is from a paper by IIr. J. W. J. K. Vauston, read before the Canadian Section of the Society of Chemical In lustry in $J_{a n}$, 1903.

${ }_{66}$ Capital stock, 1,090,000 dols.

67 Bureau of Mines Report, Ontario, 1902. 
There bas been a slight falling off in the production of oil during the past years: calculated as "crude" oil, the output in 1891 was 27 million imperial gallons, and in 1901 a little over $2 \hbar \frac{1}{2}$ million. ${ }^{68}$ A slow process of diminution seems to be going on in the area at present productive, and a falling off must be looked for from year to year unless this is counteracted by an extension of the oil-bearing territories. ${ }^{67}$ Probably, the field about to be exploited in the North-west will alter the position somewhat, and au increase in the output may be confidently looked for. ${ }^{69}$

\section{XIII.-Pulp and Paper.}

Pulp.-As timber is one of the chief natural products of the Dominion, it is only to be expected that Canada should figure largely in the wood-pulp industry; the figures that might be given to indicate the number of cords of pulpwood available throughout the country are so large that one could hardly grasp their real significance. The industry is not so young as many others that have been considered : in the census of 1871 , no pulp-making plants are mentiosed; in 1881 , there appear five mills, employing 68 men, and having an output valued at 63,000 dols.; in 1891 there were 24 , with a yjeld valued at more than a million dollars; while 1901 shows some 35 factories from which the exported pulp alone amounted to nearly 2 million dollars..$^{70}$ The area of pulp-making operations is not confined to any one province, New Brunswick, Nova Scotia, Quebec, Ontario, and British Columbia all being represented in the industry.

The principal woods employed for pulp-making are white and black spruce, balsam, poplar, and pine; spruce ${ }^{\pi 1}$ and balsam are ttose most generally used, on account of the special quality of their fibre and their colour, pine being utilised mostly for chemical pulp. Tihe two main varieties of the pulp are mechanical and chemical. The

68 Statistical Year Book, 1901.

c9 Total value of products of petroleum in Ontario in 1901, 1,467,940 dols. Bureau of Mines Report, 1902 .

;o Statistical Year Book, 1901.

7 In 1594 it was estimated that Canada contained between 38 and 40 per cent. of woodlands and forests, or about $1,400,000 \mathrm{sq}$. miles, one-half of this being spruce. The spruce area is thus 450 million acres. In all there are 4,500 million tons of pulpwood in sight. ["Pulpw ood of Canada." Pan-American Exhibition pamphlet, published by the Geological Survey, 1901.] 
former is obtained by grinding spruce logs to powder, the logs being pressed against a rapidly revolving grindstone, with water constantly supplied to prevent the friction causing a rise of temperature. A liquid pulp is thus obtained from which the water is squeezed by hydraulic machinery, a pressure of many tons to the square inch being employed. The rtsulting pulp still contains water, however, to the extent of from 50 to 60 per cent., though some works-notably those at Sault Ste. Marie-have introduced a machine specially cunstructed for the purpose of removing this large excess of moisture. Where the pulp is to he made at once into paper, this drying process is unnecessary. The spceially dried pulp resembles paper very closely in outward appearance. ${ }^{72}$ Chemical pulp is prepared by disintegrating and extracting the resinous matter from the wood-in the form of ehips-by digestion with sulphur compounds, usually a weak solution of sulphurous aeid, about a quarter of which is in the form of bisulphite of lime..$^{3}$ A soda chemical process is also employed by some makers. The sulphurous acid is either made from sulphur imported from sicily, or obtained by burning pyrites. ' Chemical pulp possesses many advantages over meclianical pulp, though its manufacture is necessarily more expensive, and the yield per eord of wood, as compared with the latter, is mueh less..$^{-4}$ It has a longer and tougher fibre, and, the resinous matter being no longer contained in it, finds uses for qualities of paper for which the mechanical pulp would be unsuitable. The principal markets for pulp are Great Britain, the United States, France, Australia, and Japan. Much of it is used, however, locally for the manufacture of paper.

Paper.-In many cases the producers of pulp also manufactnre it into paper. The principal requisites for the paper industry are a plentiful supply of pulp-wood, good water and an abundance of it, and cheap power; all these can be found in wany parts of Canada. The growth in the demand for paper of all kinds, news, wrapping, wall, and the finer grades, was one of the features of last century-especially news paper. The introduction of wood fibre into

72 The Saulte Ste. Marie Works use some $\$ 00$ tons of spruce logs, yielding 150 tons of pulp per day.

${ }_{73}$ Letter from Mr. Carl Riordan, Merriton, Ont.

7t One toll of mechanical pulp requires a little over a cord of wood; 1 ton of chemical pulp requires a little crer two cords of wood. 
its manufacture has consequently enahled the supply to keep pace with the demand. The process of manufacture requires no description here; the secretary to a prominent Canadian firm states that originally they used rope as a raw material, then straw, which was abandoned for rags, and finally these gave place to chemical and ground wood-pulp. Previous to 1870 no wood whatever was used in the manufacture of paper in this country. Ground wood-pulp was introduced at that time, and has become the filling material of the cheaper grades of paper, being partly pasty and partly fibrous. Up to 1885 the real fibre - the framework of the paper-was supplied by rags. In 1885 sulphite pulp was introduced and has largely replacel rags, except in the higher grades of paper, in which linen is used, and in the very low grades, where straw is employed..$^{75}$

The "Toronto Globe" of March 4th, 1903, in an article on the wood-pulp industry, gives the following statistics, which are of interest :-

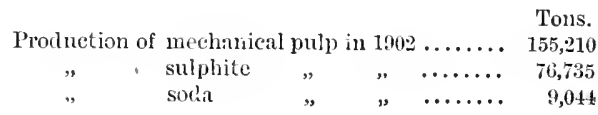

\section{XIV.-Asbestos.}

This mineral occurs in large deposits in the "Eastern Townships" of Quebec, where it wás first worked in 1878; from $1880 \mathrm{up}$ to the present date the production of asbestos has increased steadily; the output that year is given as 380 tons, while in 1901 over 38,000 tons are recorded in the return furnished by the producers. The world's supply of asbestos is, for the most part, obtained from Canada, and the Quebec deposits have in the past proved to be the most profitable mineral mined in the province. Thirteen mining companies are at work in this industry, which is principally carried on at Thetford, Lac Noir, and Danville, ${ }^{76}$ giving employment to approximately 1,000 men. Asbestos is shipped largely to Great Britain, the United States, Belgium, Germany, and France.

Another silicate found in Canada is mica, which, though occurring in small quantities, is a not unimportant industry ;

75 Mines Report, P.Q., 1901.

76 See note 73. 
in Ontario there are several mines and a number of works where splitting, trimming, and sorting the mineral into salcable sizes is carried on. Most of these, however, are on a small scale.

\section{Conclusion.}

The subjects that have been considered in this paper do not by any means exhaust the catalogue of chemical industries in Canada. Many important manufactures have, for the reasons mentioned in the opening paragraph, been omitted. A short summary of these will suffice. Matches, for example, constitute an important and necessary article of daily use, and are made in enormous quantities, practically all that are used in Canada being manufactured in the country. Brewing and distilling are also carried on extensively, ale, lager beer, and stout being made, while Canadian rye whiskey is known throughout the whole English-speaking world; even a "Canadian Scotch" is produced at Perth, Ont.; brandy and champagne and other wines are made at Hamilton, Brantford, and Pelee Island, on-Lake Erie. Fruit canning is one of the great industries of Weutworth and Essex counties, Ont.; bacon packing and salmon canning may also. be classed among those manufactures requiring the careful supervision of the skilled chemist. To the list may be added explosives of all kinds ; blackings, varnishes, japans, lacquer, paints and shellac, foodstuffs and sauces; antitoxins for use in the practice of medicine are made by the Parke Davis Co. at Walkerville. Natural mineral waters are abundant at St. Catharines in British Columbia, and in Quebee, while manufactured aerated waters are made in nearly all the important towns. The almost universal wearing of india-rubber foot coverings during the winter season necessitates the production of large quantities of goods of this sort. Many large factories for this purpose are in existence, from which rubber goods of a superior quality emanate; dyeing and calico-printing might also bc mentioned as being in a flourishing condition. The attitude of manufacturers towards chemists has of late years been extremely favourable and many have seen it to be to their advantage to employ men trained in our universities to investigate the processes and materials employed in their particular industries. So far their employment has been amply justified by the results, and it is to be hoped that more may be brought to sce the profit to be gained by

$$
\text { P 7298. }-5 \text {. }
$$


adopting scientific methods of work. The university man who has specialised in chemistry can assist the manufacturers in this by bringing to bear on the rationale of the technical processes the gencral scientific knowledge which he has gained during his college course, and his experience of methods of research and manipulation; he can thus materially benefit his employer by improving the quality of his products or enabling him to turn out his goods at a cheaper rate. Let the manufacturer, be he dyer, tanner, pulp-maker, or ironmaster, indicate only that he is willing to find employment for men educated in the higher branches of scientific work, and the universities of the Dominion will supply them. Where chemical processes are used, it is essential for the prosperity of this country that all the available scientific knowledge should be brought to bear on thew, in order that they may continue to improve and to develop even more than they have done in the past decade. Canada, with its immense natural resources, and its water power should, in time and with proper management and assistance in the lines indicated, become one of the largest producers of the world's supplies.

In conclusion I wish to acknowledge the great assistance I have received from Mr. Fred. P. Clappison, B.A., Fellow in Political Science in the University of Toronto, in gathering together for me from all quarters, the information required for this short and imperfect account of the chemical industries of the Dominion. In particular his help in connection with the statistics contained in the text and in the appendices has been invaluable. 'To the gentlemen who so kindly answered our enquiries as to their particular industries and placed valuable material at our disposal, I desire also to convey my hearty thanks.

\section{A ppendix 1.}

\section{The Iron Ores of Canada.}

Nova Scotia.-Magnetites in enormous quantities at Nictaux, in Annapolis County, at Whyhogomah, in Inverness County. Specular and red haematite at Nictaux, Stewiacke, Picton. Antigonish, Guysboro, East Bay, and many other points. Limonite, specular, spathic clay ironstone and haematite at Londonderry. Mineral fuel and 
fluxes are in close proximity throughout the whole district.77

Cape Breton.-Extensive deposits of brown haematite, magnetite, and spathic ores lying adjacent to the great coalfields. s

New Brunswick.-Magnetite and bog ores. Coalfields at Grand Lake and hardwood throughout the Province.

Province of Quebec.-Very extensive deposits of bog and lake ores, extending from the Province of Ontario to Gaspé. Maguetite deposits especially good at Skerorooke, Leeds, Sutton, St. Jerome, and in Pontiac Connty. Hardwood and limestone abundant. Deposits of chromeironstone found in 1895 in Coleraine. The "Eastern Townships" obtain iron by dredging in the Lac-a-la-Tortue. Magnetites at Hull, near Ottawa.99

Ontario.-.Vast deposits from the Ottawa Valley to head of Lake Superior, comprising magnetite, red haematite, limonite, specular, and occusionally bog ores. The Helen Mine, at Michipicoten, is said to bc one of the richest in the world. There are also exteusive forests of hardwood, especially suited for the production of charcoal, and fluxes in abundance. ${ }^{80}$

Manitoba.-Maguetite, haematite, and bog ore on Lake Winnipeg. Hardwood in abundance. ${ }^{81}$

British Columbia.-Nagnetic ores at Texada Island and Cherry Tree Blnff. Coal and wood in plenty. Collieries at Nanaimo (Naval coaling station for H.M.'s ships), Wellington, and Comox. A recent discovery of large deposits of magnetite has been reported in the Boundary Region, which at present mainly finds a use as a flux. ${ }^{.1}$

77 Nova Seotia Report of Mines, 1901.

78 Report of Geologieal Survey.

79 Mines and Minerals of Quebec: Department of Bines.

80 Burean of Mines Report, Ontirio, 1901.

81 Geologieal Survey of Canadi, 11th Annual Report. 


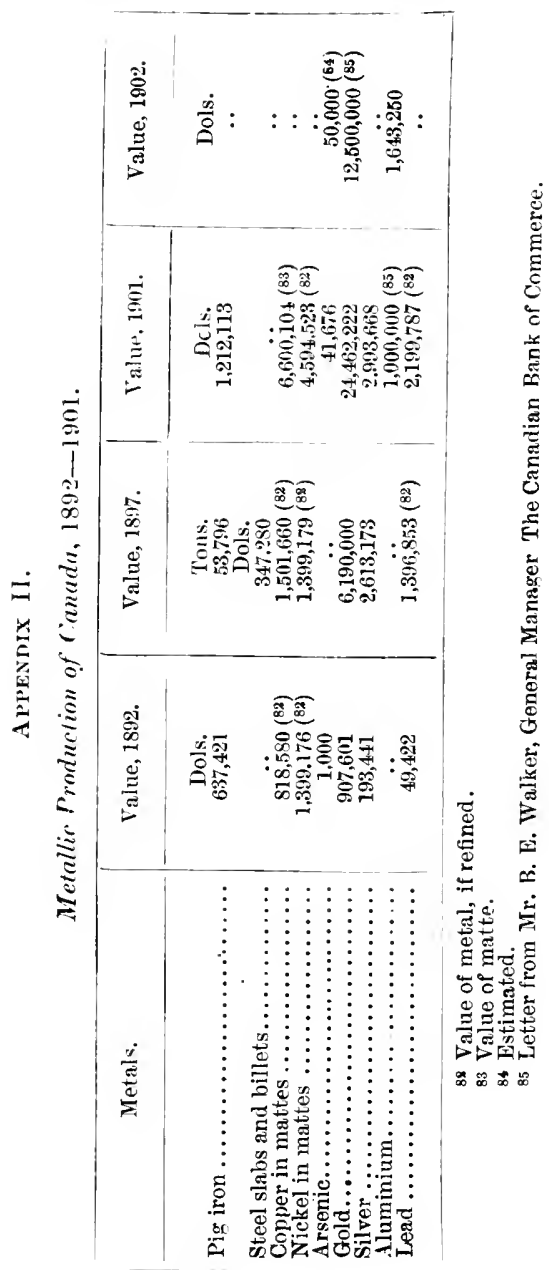


THE SOCIETY OF CHEMICAL INDUSTRY.

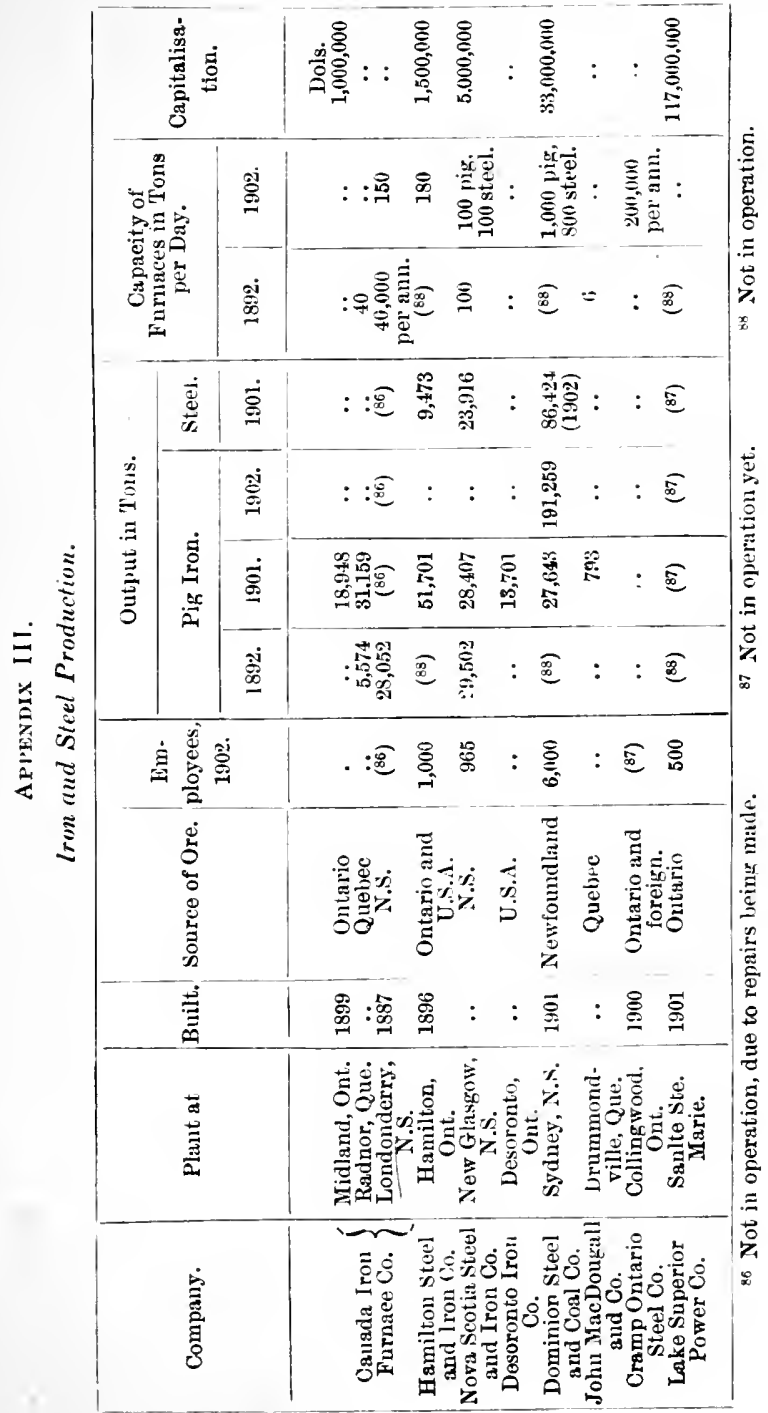




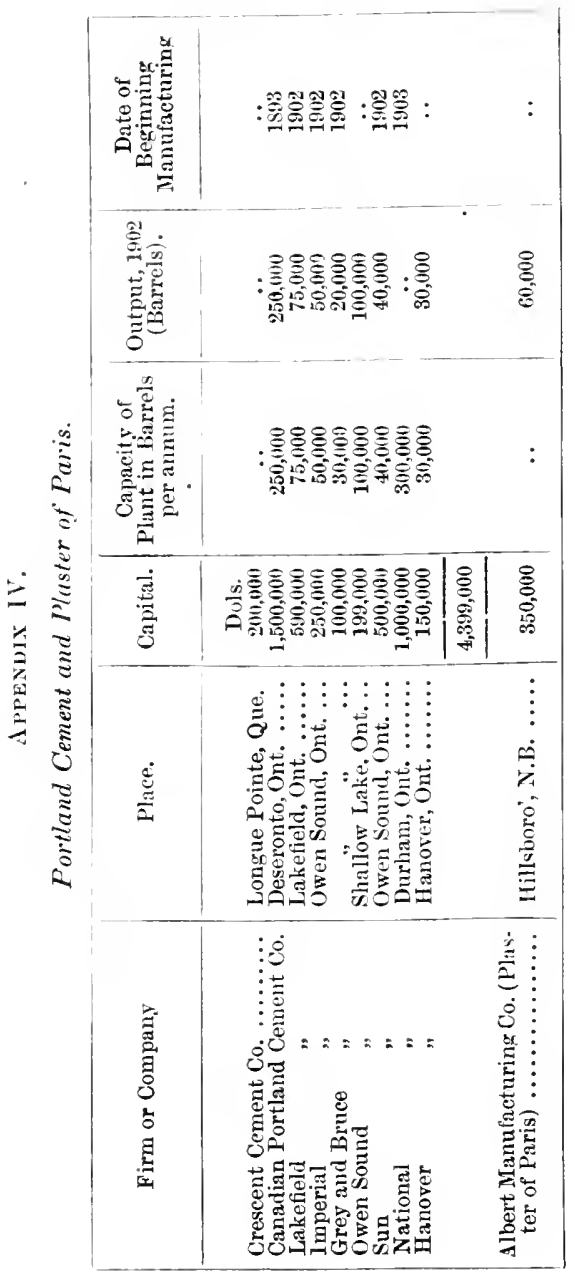




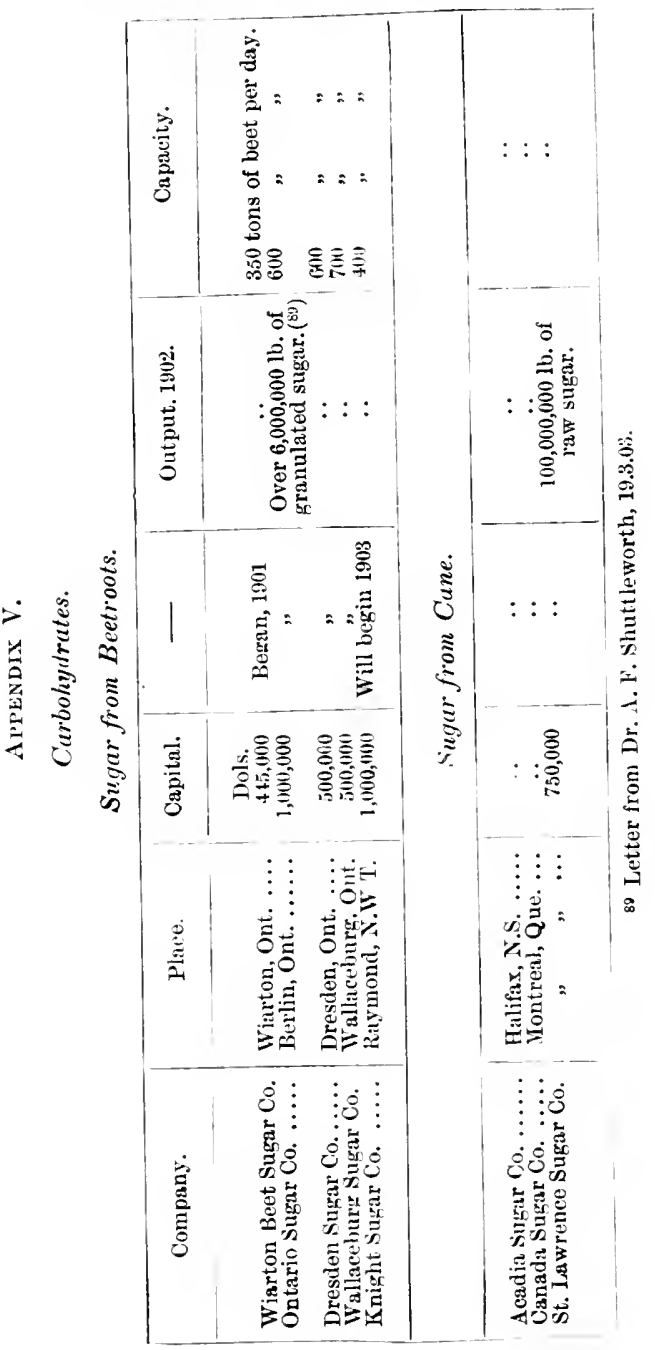







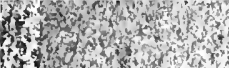

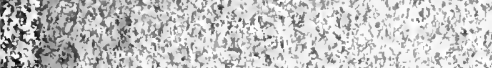

Q.

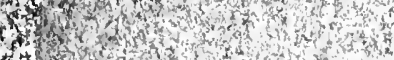

Fon

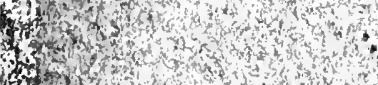
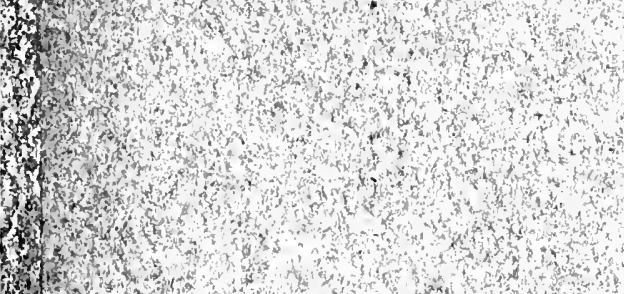

162.

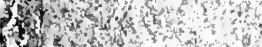




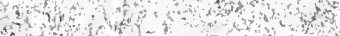




HD

9655

C22L3
Lang, William Robert

The chemical industries of Canada

\section{PLEASE DO NOT REMOVE CARDS OR SLIPS FROM THIS POCKET}




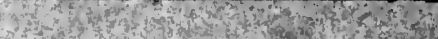

